\title{
PEMANFAATAN PRODUK UREA LEPAS LAMBAT BERBASIS TEPUNG PUTAK DALAM RANSUM SAPI BALI DI KELOMPOK PETERNAK DESA BAUMATA UTARA, KABUPATEN KUPANG
}

\section{UTILIZATION OF SLOW RELEASE UREA PRODUCT BASED PUTAK FLOUR IN BALI CATTLE RATION IN NORTH BAUMATA VILLAGE LIVESTOCK GROUP, KUPANG DISTRICT}

\author{
Emma Dyelim Wie Lawa ${ }^{1)}$, Edwin Jermias Lodowik Lazarus ${ }^{2 *}$, Matheos Filipus Lalus ${ }^{3)}$ \\ ${ }^{1)}$ Fakultas Peternakan, Universitas Nusa Cendana. email: emmalawa@staf.undana.ac.id \\ ${ }^{2}$ Fakultas Peternakan, Universitas Nusa Cendana. email: edwinlazarus@ @staf.undana.ac.id \\ ${ }^{3)}$ Fakultas Peternakan, Universitas Nusa Cendana. email: matheoslalus@staf.undana.ac.id
}

\begin{abstract}
ABSTRAK
Permasalahan mitra kelompok tani ternak di desa Baumata Utara adalah rendahnya pengetahuan akan penyediaan pakan sapi yang bermutu dan dapat memenuhi kebutuhannya. Tujuan kegiatan ini adalah memberikan penyuluhan dan pelatihan tentang pembuatan produk pemasakan urea dengan tepung putak dan penggunaannya dalam pakan konsentrat sebagai suplemen ransum ternak sapi. Metode kegiatan adalah, 1) penyuluhan tentang teknologi pemasakan urea dengan tepung putak dan pemanfaatannya dalam ransum sapi; 2) praktek, pembuatan produk pemasakan urea dengan tepung putak, praktek pencampuran produk tersebut dalam pakan konsentrat dan penerapan pemberiannya sebagai pakan suplemen pada ternak sapi dan 3) evaluasi kegiatan secara umum bersama mitra untuk mendapatkan input dan feedback bagi kegiatan di waktu mendatang. Hasil kegiatan menunjukkan 1) peternak mitra sangat antusias menerima inovasi baru di bidang penyediaan pakan bagi ternak sapi; 2) Hasil diskusi dan evaluasi verbal maupun praktek menunjukkan mitra paham dan dapat mengaplikasikannya; 3) Adanya harapan untuk keberlanjutan kegiatan sejenis di waktu mendatang. Disimpulkan bahwa kegiatan ini sangat diapresiasi oleh peternak mitra karena teknologi pemasakan urea-tepung putak dan penggunaannya dalam ransum konsentrat bagi ternak sapi yang diinformasikan ini memberi wawasan bagi peningkatan sistem pemeliharaan ternak sapi dalam pemenuhan kebutuhan gizinya. Adanya keterbukaan mitra dalam menerima inovasi baru ini.
\end{abstract}

Kata kunci: Inovasi, Suplemen, Urea Lepas Lambat, Tepung Putak, Sapi Bali

\section{ABSTRACT}

The problem with the partners of the livestock farmer groups in Baumata Utara village is the lack of knowledge about the supply of quality cattle feed that can meet their needs. The purpose of this activity is to provide counseling and training on the manufacture of urea cooking products with putak flour and its use in concentrate feed as a supplement for cattle rations. The methods of activity are, 1) counseling on the technology for cooking urea with putak flour and its use in cow rations; 2) practice, manufacture of urea cooking products with putak flour, practice mixing these products in concentrate feed and applying it as supplementary feed for cattle and 3) general evaluation of activities with partners to get input and feedback for future activities. The results of the activity show 1) partner breeders are very enthusiastic about receiving new innovations in the field of providing feed for cattle; 2) The results of the discussion and evaluation of verbal and practice show that partners understand and can apply it; 3) There is hope for the sustainability of similar activities in the future. It is concluded that this activity is highly appreciated by partner breeders because the technology for cooking urea-putak flour and its use in concentrate rations for cattle provides insight into improving the system for raising cattle in meeting its nutritional needs. There is openness partners in accepting this new innovation.

Keywords: Innovation, Supplements, Slow Release Urea, Putak Flour, Bali Cattle

Corresponding author: 
PENDAHULUAN

Produktivitas ternak sapi khususnya sapi Bali yang banyak dipelihara masyarakat di Nusa Tenggara Timur (NTT) selalu mengalami fluktuasi mengikuti perubahan musim kering dan musim hujan. Pada musim hujan ketika produksi dan kualitas hijauan rumput alam meningkat maka ternak sapi akan bertumbuh dengan baik, namun sebaliknya pada musim kering terjadi penurunan produksi bahkan kematian ternak akibat kekurangan pakan. Kondisi di lapangan menunjukkan bahwa pada musim hujan sapi dapat bertumbuh 0,40-0,50 $\mathrm{kg}$ /ekor/hari namun pada musim kering terjadi penurunan bobot badan 0,15-0,27 kg/ekor/hari [1]. Fenomena ini juga banyak terjadi di daerah tropis lainnya di dunia dimana umumnya ternak ruminansia diberi pakan berupa hijauan berkualitas rendah, jerami tanaman pertanian, hasil ikutan (by product) industri yang pada dasarnya mengandung materi ligno-selulosa yang tinggi dan karbohidrat terfermentasi atau kualitas protein yang rendah [2]. Kondisi seperti ini mengakibatkan ternak mengalami kehilangan berat badan. Solusi yang ditawarkan adalah perlunya pemberian pakan tambahan atau suplemen untuk menstimulus pertumbuhan ternak. Hasil penelitian menunjukkan bahwa dengan pemberian pakan suplemen, pertumbuhan sapi Bali meningkat $0,1-0,2 \mathrm{~kg} / \mathrm{ekor} / \mathrm{hari}$ pada musim hujan dan dapat menurunkan kehilangan berat badan dari $0,25 \mathrm{~kg} / \mathrm{ekor} / \mathrm{hari}$ menjadi $0,15 \mathrm{~kg} / \mathrm{ekor} / \mathrm{hari}$ pada musim kemarau [3].
Penggunaan suplemen protein dalam

ransum tenak sapi haruslah efisien karena selain merupakan nutrien yang sangat penting harganya juga mahal [4]. Untuk itu diperlukan mencari berbagai alternatif bahan lain yang setara manfaatnya dengan protein dalam meningkatkan produktivitas ternak sapi. Urea merupakan sumber nitogen bukan protein yang dapat digunakan menggantikan protein murni bagi ternak sapi. Penggunaannya sebagai suplemen sumber nitrogen memerlukan kombinasi dengan pakan sumber karbohidrat mudah terfermentasi. Upaya untuk meningkatkan pemanfaatan urea sebagai suplemen adalah dengan mengupayakan pelambatan pelepasannya menjadi amonia di dalam rumen sapi sehingga dapat dimanfaatkan dengan efisien oleh mikroba rumen. Pelambatan pelepasan amonia tersebut harus dilakukan dengan mensinkronkan energi dari pakan sumber karbohidrat dengan urea [5]. Salah satu sumber energi yang banyak tersedia di pulau Timor adalah isi batang (umbut) pohon gewang (Corypha utan Lamk.) yang dikenal peternak dengan nama putak. Putak mengandung pati yang cukup tinggi yang dapat dimanfaatkan sebagai sumber energi bagi ternak. Pengetahuan akan pelambatan sinkronisasi urea dengan putak ini perlu diberikan kepada peternak agar mereka lebih cerdas, cermat dan cepat mengantisipasi penyediaan pakan yang berkualitas bagi sapi mereka. Tujuan pelaksanaan Program Kemitraan Masyarakat ini adalah memberikan informasi melalui 
penyuluhan dan pelatihan kepada peternak mitra tentang teknologi pemasakan urea dengan tepung putak dan pemanfaatannya dalam ransum sapi.

\section{METODA PELAKSANAAN KEGIATAN}

Pelaksanaan kegiatan Program

Kemitraan ini dibagi dalam tahap, 1) tahap persiapan, tujuannya adalah untuk mempersiapkan peternak dan penentuan jadwal kegiatan sesuai kesepakatan dengan peternak mitra., 2) tahap pelaksanaan kegiatan yang dilakukan berupa, a) penyuluhan kepada mitra tentang sistem pemeliharaan ternak sapi, jenis dan penyediaan pakan khususnya teknologi pemasakan untuk menghasilkan produk urea lepas lambat, b) pendidikan dan pelatihan berupa teknik pembuatan produk urea lepas lambat berbasis tepung putak dan pencampurannya dengan bahan lain untuk digunakan dalam ransum sapi dan pemberiannya pada ternak sapi sebagai pakan suplemen.

Materi yang disiapkan dalam kegiatan ini adalah bahan pakan yang terdiri dari Dedak padi, jagung giling, bungkil kelapa, tepung putak, urea, produk pemasakan ureatepung putak, mineral dan vitamin dan ternak sapi peternak yang sementara dikandangkan. Peralatan yang digunakan antara lain, peralatan masak berupa dandang besar, baskom, pengaduk, gelas ukur, timbangan dan lain-lain.

Prosedur Pelaksanaan Kegiatan Praktek 1. Pemasakan Urea dengan Tepung Putak

Putak dalam bentuk serbuk (tepung) sebanyak 1.000 gram (1 kilogram) atau setara dengan 2 kaleng ukuran sedang (1 kaleng berisi 0,5 kilogram) dicampur dengan urea (3\% dari jumlah tepung putak $=3 / 100 \times 1000$ gram $=30$ gram atau setara dengan 1 sendok makan)), dilarutkan dengan air (60\% dari jumlah campuran kedua bahan $=60 / 100 \mathrm{x}$ $1030=618$ atau setara dengan 0,6 liter) menjadi adonan sesuai Widyawati (2010) [6]. Adonan campuran bahan tersebut dimasukan dalam wadah (bisa dari kaleng berpenutup atau plastik tahan panas) sesuai jumlah yang akan dimasak, kemudian dimasukan dalam wadah tertutup dan dimasak dalam wadah di atas kompor selama 1 jam. Bahan tersebut dimasukan dalam wadah pemasakan setelah air dipanaskan mendidih. Setelah 1 jam, produk pemasakan tersebut diangkat, didinginkan dan dikeringkan/dijemur. Produk kemudian dihaluskan dan dicampur dalam ransum

\section{Penggunaan dalam Ransum}

Ransum untuk sapi disusun dengan perbandingan hijauan : konsentrat dalam perbandingan 60:40. Penentuan kebutuhan PK sapi sesuai umur pertumbuhannya, misalnya sapi $\mathrm{BB} 150 \mathrm{Kg}$, Kebutuhan PK $12 \%$. Susunan ransum sebagai berikut:

\begin{tabular}{|l|c|c|}
\hline Bahan Pakan & $\begin{array}{c}\text { Kandungan } \\
\text { PK }\end{array}$ & $\begin{array}{c}\text { Jumlah } \\
\text { Pemberian }\end{array}$ \\
\hline Jerami padi & 4,9 & 50 \\
\hline Bungkil kelapa & 38,5 & 12 \\
\hline Dedak padi & 12 & 10 \\
\hline Jagung giling & 10,67 & 8 \\
\hline $\begin{array}{l}\text { Produk } \\
\text { pemasakan } \\
\text { urea-putak }\end{array}$ & 12,24 & 20 \\
\hline
\end{tabular}


ditempatkan peternak sebagai usaha

$\mathrm{BB}$ sapi $150 \mathrm{~kg}$. Estimasi kebutuhan $\mathrm{BK}=$ $2,5 \% \mathrm{BB}=3750 \mathrm{gram} / \mathrm{e} / \mathrm{h}=3,75 \mathrm{~kg}$

Jerami padi $=50 / 100 \times 3750=1875$ gram

Konsentrat $=50 / 100 \times 3750=1875$ gram

Susunan konsentrat sebagai berikut :

- Bungkil kelapa $=12 / 100$ x $3750=450$ gram (1,5 bagian)

- Dedak padi $=10 / 100 \times 3750=375$ gram (1,25 bagian)

- Jagung giling $=8 / 100 \times 3750=300$ gram (1 bagian)

- Produk pemasakan=20/100x3750=750gram (2,5 bagian)

\section{Pemberian pada ternak sapi}

- Berikan setengah pada pagi hari dilanjutkan pemberian jerami padi

- Setengahnya diberikan sore hari dilanjutkan pemberian jerami padi

\section{HASIL DAN PEMBAHASAN}

Kegiatan PKM ini diikuti 15 orang peserta yang memiliki dan memelihara ternak sapi. Ternak sapi yang dipelihara mitra adalah jenis sapi Bali dengan sistem pemeliharaan yang diterapkan adalah intensif dan semi intensif. Kebanyakan mitra peternak membagi waktu di dalam keseharian pekerjaannya, yaitu usaha pertanian hortikultura dan peternakan sehingga pola pemeliharaan ternak semi intensif lebih menonjol dibanding intensif. Melalui pola pemeliharaan ini, peternak dapat menggunakan waktu lebih banyak di bidang tanaman pertanian dan sebagian waktu disisihkan untuk usaha ternak sapi. Pada umumnya usaha sapi potong sampingan dan ini berkonsekuensi curahan waktu, curahan biaya serta investasi untuk usaha peternakan tidak menjadi perhatian utama peternak [7].

Pola usaha ternak sapi intensif dilakukan untuk beberapa ternak yang difokuskan pada penggemukkan, dimana semua kebutuhan ternak dipenuhi oleh peternak sendiri. Penerapan pemberian pakan suplemen dapat diaplikasikan pada kedua sistem peternakan yang dilakukan peternak. Usaha peternakan yang dilakukan secara intensif sangat berkaitan erat dengan inovasiinovasi di bidang peternakan [8]. Akan tetapi terkadang peternak sulit menerima suatu perubahan atau hal yang baru, mereka telah merasa puas dengan apa yang mereka jalankan walau terkadang hasilnya kurang memuaskan.

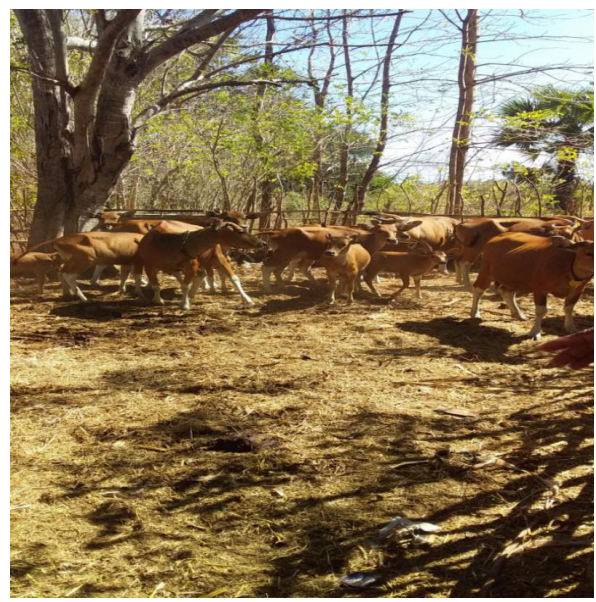

Gambar 1. Sistem peternakan sapi semi intensif peternak mitra

Sistem peternakan yang dilakukan peternak mitra akhirnya lebih bergantung pada kondisi alam dengan ketersediaan pakan sesuai musim dan ini sangat mempengaruhi pertumbuhan ternak sapi. Ternak sapi yang digembalakan akan mengalami pertambahan 
bobot badan sebesar 0,3-0,6 kg/hari selama musim hujan, namun mengalami kehilangan berat badan mencapai $0,35 \mathrm{~kg} / \mathrm{hari}$ selama musim kemarau $[9,10]$. Rumput alam yang diandalkan peternak mitra sebagai pakan utama sapi kualitasnya rendah sehingga mempengaruhi upaya percepatan pertumbuhan sapi. Rumput alam umumnya memiliki kandungan nutrisi yang sangat rendah yaitu kandungan protein kasar 6-8\%, TDN $60 \%$ dan Serat kasar 28,06\% [11]. Kondisi rumput alam demikian yang dihadapi peternak mitra dalam usaha ternak sapinya.

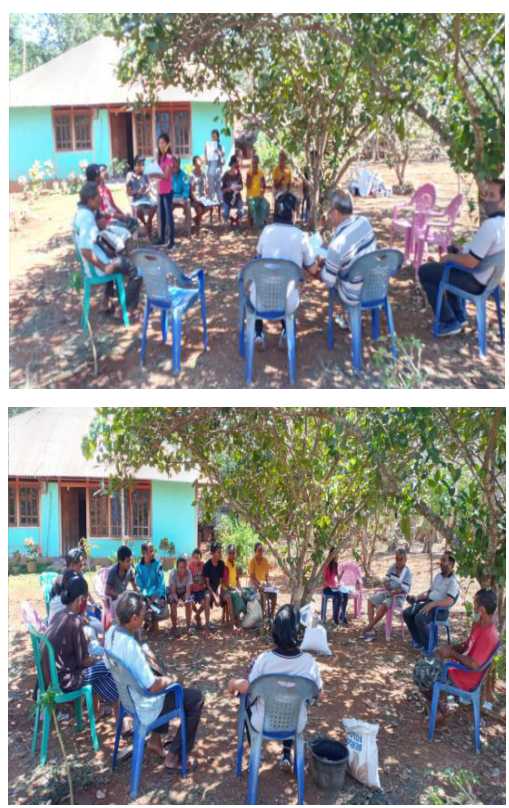

Gambar 2. Suasana penyuluhan dikemas model dialog

Peternak mitra diajak berdiskusi tentang penyediaan pakan bagi sapi dan pentingnya suplementasi dalam sistem peternakan yang diterapkan peternak mitra. Diskusi lebih diarahkan pada pentingnya teknologi untuk mensinkronkan atau menyeimbangkan bahan pakan sumber karbohidrat dan protein atau NPN (Non Protein Nitrogen) dalam hal ini urea di dalam ransum. Kedua bahan pakan ini diharapkan nantinya secara efisien dan optimal tersedia bagi ternak sapi yang mengkonsumsi pakan basal rumput alam atau jerami padi. Kandungan karbohidrat mudah larut yang rendah disertai serat kasar yang tinggi, menyebabkan kecernaan rumput lapangan sebagai pakan basal sapi menjadi rendah dan membatasi konsumsi pakan [12]. Kondisi demikian mengakibatkan ternak sering mengalami kekurangan nutrisi.

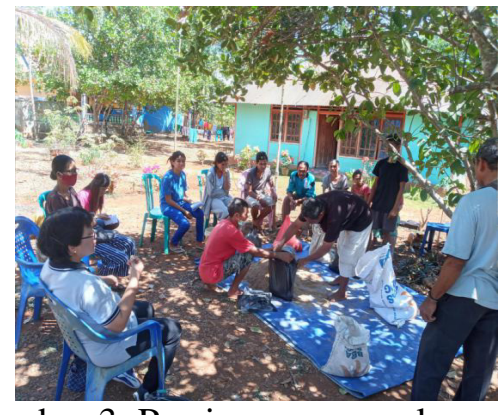

Gambar 3. Persiapan pemasakan urea tepung putak
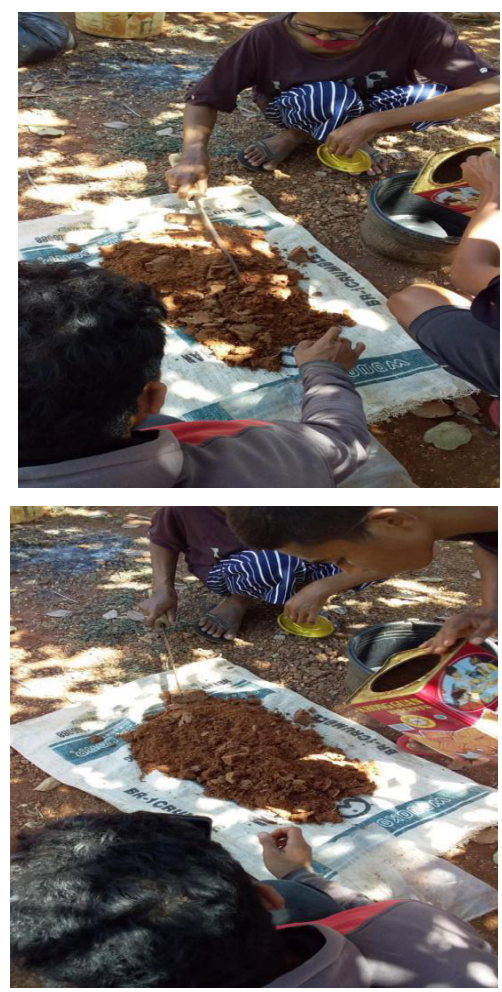

Gambar 4. Produk pemasakan urea-tepung putak

Produk hasil pemasakan urea-tepung putak merupakan produk yang akan 
menyediakan energi dan amonia bagi ternak melalui pemanfaatan oleh mikroorganisme rumen. Peternak mitra diberikan pemahaman tentang pentingnya sinkronisasi energi dan nitrogen/protein dalam pencernaan ternak untuk menghasilkan pertumbuhan yang optimal bagi ternak. Banyak hal yang didiskusikan dengan peternak mengenai produk ini dan peternak menganggap bahwa teknologi ini tidak terlalu sulit dalam aplikasinya dalam penyediaan pakan untuk sapi. Kriteria suatu teknologi peternakan agar dapat diadopsi peternak adalah teknologi tersebut harus sederhana, tidak rumit dan mudah dilakukan peternak [13]. Teknologi pemasakan urea-tepung putak menjadi produk yang memenuhi kebutuhan ternak adalah teknologi yang mudah dilakukan peternak dan bahan baku yang digunakan juga telah dikenal dan mudah didapat. Hal ini menegaskan bahwa dalam mengadopsi inovasi teknologi pakan, aspek yang perlu diperhatikan adalah bahan bakunya tersedia di tempat, mudah dilakukan artinya semakin mudah dilakukan makin cepat proses adopsi teknologi tersebut dilakukan peternak. Selain itu biaya yang dikeluarkan peternak untuk aplikasi teknologi tersebut harus terjangkau sesuai kemampuan peternak.

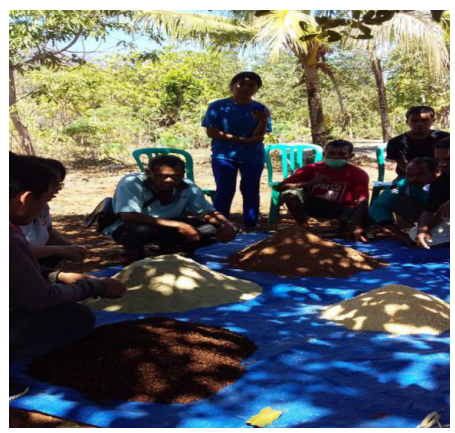

Gambar 5. Persiapan pencampuran bahan

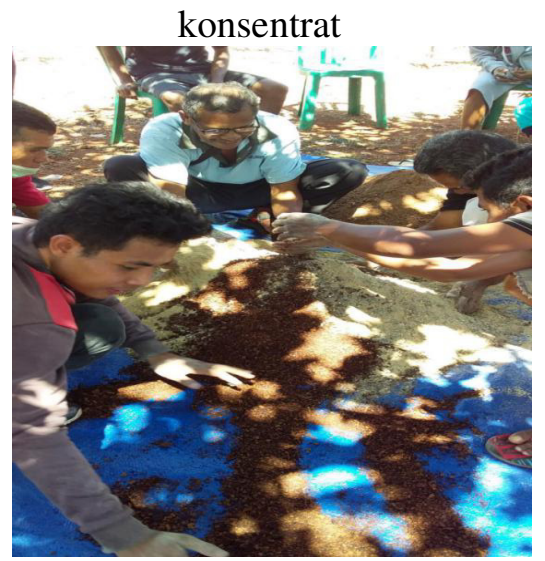

Gambar 6. Pencampuran produk pemasakan dalam konsentrat

Ransum hasil racikan peternak mitra diberikan kepada ternak sapi yang sementara dilakukan penggemukkan dan diperlukan adaptasi ternak terhadap ransum tersebut. Peternak diminta untuk memberikan produk tersebut dalam ransum untuk mendapatkan efisiensi pemeliharaan yang baik. Peternak mitra peserta kegiatan PKM ini kemudian membagi ransum konsentrat hasil racikannya untuk masing-masing dan akan diberikan untuk ternak sapi yang sementara dikandangkan.

\section{KESIMPULAN}

Kegiatan PKM ini sangat diapresiasi oleh peternak mitra karena teknologi pemasakan urea-tepung putak dan penggunaannya dalam ransum konsentrat bagi ternak sapi yang diinformasikan ini memberi wawasan bagi peningkatan sistem pemeliharaan ternak sapi khususnya dalam penyediaan pakan yang didasarkan pada pemenuhan kebutuhan gizi. Aktivitas dan antusiaisme peternak mitra menunjukkan keterbukaan dalam menerima inovasi baru karena menyadari akan dampak positip bagi usaha ternak sapi yang dijalaninya. 


\section{REFERENSI}

[1] Bamualim, A dan R.B. Wirdahayati. 2002. Peternakan di Lahan Kering Nusa Tenggara. Balai Pengkajian Teknologi Pertanian Nusa Tenggara Timur, Kupang. 120 hlmn.

[2] Khampa, S. and M. Wanapat. 2007. Manipulation of rumen fermentation with organic acids supplementation in ruminants raised in the tropics. Pakistan Jur. Nutr. 6 (1): 20-27.

[3] Bamualim, A.M. 2011. Pengembangan teknologi pakan sapi potong di daerah semi-arid Nusa Tenggara. Balai Pengkajian Teknologi Pertanian Nusa Tenggara Timur, Kupang. $120 \mathrm{hlmn}$.

[4] Cherdthong, A. and M. Wanapat. 2010. Development of urea product as rumen slow-release feed for ruminant production: A Review. Aust. J. Basic and Appl. Sci. 4 (8): 2232-2241.

[5] Harrison, G.A. and T.P. Karnezos. 2005. Can we improve the efficiency of nitrogen utilization in lactating dairy cows. Pp 145-154. In: Recent Advances in Animal Nutrition. Vol. 15. T.P. Lyons and K.A. Jacques (ed), Altech Inc., Australia.

[6] Widyawati, S.D. 2010. Teknologi gelatinisasi pada pakan sumber energi dan suplementasi asam amino sebagai upaya optimalisasi pertumbuhan ternak ruminansia. Caraka Tani XXV. 1 : 63-71

[7] Baba, S., A. Muktiani., A. Ako dan B. Ibrahim. 2013. Hambatan adopsi teknologi integrasi jagung dan ternak sapi di Sulawesi Selatan. Prosiding Seminar Nasional Peternakan Berkelanjutan. 12-13 November 2013, Bandung.

[8] Lamarang, Z., B.F.J. Sondakh., A.K. Rintjep dan A.A. Sajow. 2017. Peranan penyuluh terhadap pengambilan keputusan peternak dalam adopsi inovasi teknologi peternakan di kecamatan Sangkub Kabupaten Bolaang Mongondow Utara. Jurnal Zootek. 37 (2) : 496-507.

[9] Marawali, H dan A. Bamualim. 1995. Monitoring produktivitas sapi Bali di Kabupaten Bobonaro, Propinsi Timor Timur. Proseding Seminar Komunikasi dan Aplikasi Hasil Penelitian Peternakan Lahan Kering. Balai Penelitian Ternak, Lili, Kupang.

[10] Nggobe, M., A. Bamualim dan R.B. Wirdahayati. 1995. Pengaruh pengaturan pola perkawinan terhadap pertumbuhan dan tingkat kematian anak sapi Bali di pulau Timor. Proseding Seminar Komunikasi dan Aplikasi Hasil Penelitian Peternakan Lahan Kering. Balai Penelitian Ternak, Lili, Kupang.

[11] Mathius, I W., D. Yulistiani dan W. Puastuti. 2002. Pengaruh sustitusi protein kasar dalam bentuk bungkil kedelai terproteksi terhadap penampilan domba bunting dan laktasi. JITV. 7 (1) : 22-29.

[12] Melati, N.P.Y., I G.L.O. Cakra dan I B.G. Partama. 2019. Pengaruh penggantian pollard dengan dedak padi yang disuplementasi multivitaminmineral dalam konsentrat terhadap penampilan sapi bali jantan. Majalah Ilmiah Peternakan. 22 (1) : 1 - 9.

[13] Abdullah, A. 2016. Proses adopsi teknologi fermentasi jerami padi sebagai pakan sapi potong pada peternakan rakyat di Kabupaten Bulukumba, Sulawesi Selatan. Sosiohumaniora. 18 (1) : $1-8$. 